\title{
ANALISIS TIPE KEPEMIMPINAN DIREKTUR OPERASIONAL TERHADAP KUALITAS KINERJA PEGAWAI PT. ADHYA TIRTA BATAM (ATB)
}

\section{ANALYSIS OF LEADERSHIP TYPE OF OPERATIONAL DIRECTORS ON QUALITY OF EMPLOYEE PERFORMANCE PT. ADHYA TIRTA BATAM (ATB)}

\author{
Khoirul Anwar ${ }^{1}$, Linayati Lestari ${ }^{2}$ \\ ${ }^{1}$ (Prodi Ilmu Pemerintahan, Fakultas Ilmu Sosial \& Ilmu Politik, Universitas Riau Kepulauan, Indonesia) \\ ${ }^{2}$ (Prodi Ilmu Pemerintahan, Fakultas Ilmu Sosial \& Ilmu Politik, Universitas Riau Kepulauan, Indonesia) \\ ${ }^{1}$ irula06@gmail.com,2linayatilestari@yahoo.com
}

\begin{abstract}
Abstrak
Penelitian ini bertujuan untuk menganalisis tipe kepemimpinan Direktur Operasional PT. Adhya Tirta Batam (ATB) terhadap kualitas kinerja pegawai di kantor cabang WTP Dam Muka Kuning Batam. Tujuan lain dari penelitian ini adalah mengidentifikasi kinerja pegawai kantor cabang WTP Dam Muka Kuning Batam. Metode penelitian yang digunakan yaitu kualitatif. Pemilihan lokasi ini dilakukan secara sengajadengan mempertimbangkan hasil studi. Lokasi yang dipilih berdasarkan kantor divisioperasional, dimana kegiatan mengenai operasional berada di lokasi tersebut.Selain itu lokasi yan dipilih untuk mendapatkan informasi yang akurat,detail mengenai kepemimpinan direktur operasional PT. Adhya Tirta Batam (ATB). Penelitian ini menggunakan sampel sejumlah 30 responden dengan menggunakan Teknik purposive random sampling dengan berdasarkan 5 kriteria yang ditentukan peneliti.Hasil penelitian menyimpulkan bahwa direktur operasional dalam memimpin memiliki tipe kepemimpinan demokrasi dimana pegawai sangat berperan penting dalam kemajuan perusahaan. Seorang pemimpin memberikan kepercayaan dalam tugas dan wewenangnya didalam organisasi dan juga pengambilan keputusan didalam pekerjaan yang diberikan oleh perusahaan. Pegawai diberikan kebebasan untuk berinisiatif dan berinovasi terhadap perusahaan. Pemimpin juga diberikan kesempatan untuk memberikan masukan, saran, pendapat dan kritik kepada pemimpin jika keputusan yang diambil pemimpin itu kurang tepat untuk perusahaan tetapi tetap pengambilan keputusan oleh direktur operasional. Pemimpin juga menyelaraskan kepentingan organisasi dan kepentingan antara pegawainya. Selain daripada itu pemimpin selalu berusaha untuk mengutamakan kerjasama dan kerja tim dalam mencapai tujuan perusahaan, hal ini sangat berpengaruh yang signifikan untuk kemajuan dan kenyaman kerjaan pegawai.
\end{abstract}

\section{Kata Kunci : Kepemimpinan ;Kinerja ; Pegawai ; Adhya Tirta Batam (ATB)}

\begin{abstract}
This study aims to analyze the type of leadership of the Operations DirectorPT. Adhya Tirta Batam (ATB) towards the quality of employee performance at the branch officeWTP Dam Muka Kuning Batam. Another purpose of this study is to identify the performance of branch office employees WTP Dam Muka Kuning Batam. The research method used is qualitative. The location selection was done intentionally by considering the results of the study. The location chosen is based on the office of the operational division, where activities regarding operations are in that location. In addition, the location was chosen to obtain accurate, detailed information about the operational director's leadershipPT. Adhya Tirta Batam (ATB).This study used a sample of 30 respondents using purposive random sampling technique based on 5 criteria determined by researchers. The results of the study concluded that the operational director in the lead had a type of democratic leadership where employees were very important in the company's progress. A leader gives trust in his duties and authority within the organization and also decision making in the work provided by the company. Employees are given the freedom to take the initiative and innovate with the company. Leaders are also given the opportunity to provide
\end{abstract}


input, suggestions, opinions and criticisms to the leader if the decisions taken by the leader are not appropriate for the company but still make decisions by the operational director. The leader also aligns the organization's interests and interests between its employees. Apart from that leaders always try to prioritize cooperation and teamwork in achieving company goals, this has a very significant effect on the progress and comfort of employee work.

Keywords: Leadership; Performance; Employee; Adhya Tirta Batam (ATB)

\section{PENDAHULUAN}

Kepemimpinan atau leadership berasal dari kata pimpin yang berarti tuntun, bina, atau bimbing. Kepemimpinan menurut Miftah Thoha dalam bukunya yang berjudul “Kepemimpinan Dalam Manajemen” mengemukakan bahwa kepemimpinan adalah kegiatan untuk mempengaruhi perilaku orang lain, atau seni mempengaruhi perilaku manusia baik perorangan atau kelompok (Miftah Thoha, 2003).Tipe kepemimpinan dapat diartikan sebagai bentuk atau pola atau jenis kepemimpinan, yang didalamnya diimplementasikan satu atau lebih perilaku atau gaya kepemimpinan sebagai pendukungnya. Sedangkan gaya kepemimpinan diartikan sebagai perilaku atau cara yang dipilih dan dipergunakan pemimpin dalam mempengaruhi pikiran, perasaan, sikap dan perilaku para anggota organisasi atau bawahannya.

Seorang untuk menjalankan organisasi di perusahaan swasta ataupun instansi pemerintahan, yang harus dipahami oleh para pemimpin bahwa pemimpin yang baik adalah pemimpin yang mengerti dengan benar dimana ia meletakkansetiap tipe kepemimpinan tersebut sesuai dengan tempatnya. Seorang pemimpin yang tidak baik adalah pemimpin yang tidak mengerti bagaimana ia harus bersikap. Jika organisasi bersifat kondusif dan segalanya berjalan sesuai dengan rencana maka konsep tipe kepemimpinan demokratis dan partisipatif wajar untuk diterapkan. Namun jika kondisi tidak baik atau perlu penanganan serius seorang pemimpin harus mengkaji apa tipe kepemimpinan yang fleksible atau realistis untuk diterapkan (Rahmi, 2013).

Kepemimpinan merupakan suatu ilmu yang mengkaji secara komprehensif tentang bagaimana mengarahkan, mempengaruhi, dan mengawasi orang lain untuk mengerjakan tugas sesuai dengan perintah yang direncanakan (Irham, 2013). Gaya kepemimpinan masing-masing 
pemimpin dalam setiap divisi yang dipimpin erat kaitannya dengan kinerja pegawai pada divisi yang dipimpinnya. Gaya kepemimpinan yang sesuai dengan budaya kerja perusahaan tersebut secara tidak langsung akan mendukung peningkatan kinerja pegawai tersebut. Kinerja organisasi adalah sebagai efektifitas organisasi secara menyeluruh untuk memenuhi kebutuhan yang ditetapkan dari setiap kelompok yang berkenaan dengan usaha yang sistematik dan meningkatkan kemampuan organisasi secara terus menerus mencapai kebutuhan secara efektif. Dengan semakin meningkatnya kinerja pegawai pada divisi yang ditempatinya, secara tidak langsung membuat perusahaan tersebutsemakin berkembang menjadi baik, kinerja pegawai harus menjadi bagian terpenting bagi perusahaan untuk mengembangkan perusahaan menjadi lebih baik lagi.

Kinerja pegawai sangat bergantung pada gaya kepemimpinan seorang pemimpin di perusahaan tersebut. Oleh karena itu sebagai seorang pemimpin dalam suatu perusahaan harus bisa beradaptasi dengan budaya kerja perusahaan agar bisa meningkatkan kinerja pegawai perusahaan.

Penelitian ini mengambil obyek PT. Adhya Tirta batam (ATB) Kantor Cabang Water Treatment Plant (WTP) Dam Muka Kuning Batam. PT. Adhya Tirta Batam adalah suatu perseroan terbatas yang didirikan berdasarkan hukum Negara Republik Indonesia, termasuk yang didirikan secara sah berdasarkan Undang-Undang No. 1 Tahun 1967 juncto UndangUndang No. 11 Tahun 1970 tentang Penanaman Modal Asing, yang telah memiliki izin dan ditunjuk sebagai perusahaan yang memiliki hak eksklusif atau satu-satunya di Pulau Batam untuk mengambil, memanfaatkan dan mengelola air baku menjadi air bersih, serta mendistribusikannya kepada Pelanggan di Pulau Batam berdasarkan Surat Keputusan Ketua Otorita Pengembangan Daerah Industri Pulau Batam (Otorita Batam) Nomor 062/UMKPTS/XI/1995 tertanggal 15 November 1995 tentang "Pengelolaan Air Bersih di Pulau Batam oleh PT. Adhya Tirta Batam” (Moreno Ginting, 2015).

Sejak awal Pulau Batam ditetapkan sebagai kawasan industri di bawah kendali Otorita Batam pada 1971 sampai pertengahan 1990-an, pasokan air terbilang minim. Otorita Batam yang mengelola pengairan hanya bisa menghasilkan sekitar 500 liter per detik. Padahal kapasitas air baku mencapai 850liter per detik.Warga Pulau Batam tidak bisa menggali sumur 
seperti yang banyak dilakukan warga di pulau-pulau utama. Sebabnya, air tanah di Pulau Batam tergolong dangkal dan kadar keasamannya $(\mathrm{pH})$ berkisar antara 5-6. Agar bisa diminum, kadar keasaman air harus dinetralisir. Padahal, Batam disiapkan secara khusus sebagai kawasan industri untuk saling berhadapan dengan Singapura. Kondisi ini membuat gusar Ketua Otorita Batam saat itu BJ Habibie. Menteri Negara Riset dan Teknologi saat itu lalu berinisiatif melakukan pengelolaan air bersih dengan pihak swasta.

Otorita Batam kemudian melakukan studi kelayakan pengelolaan air di Pulau Batam. Lewat negosiasi yang panjang, Otorita menunjuk konsorsium PT. Adhya Tirta Batam sebagai pengelola air. Konsorsium itu terdiri dari perusahaan Biwater International, PT. Bangun Cipta Kontraktor, dan PT. Syabata Cemerlang. Seiring dengan pesatnya perkembangan Batam serta untuk memenuhi kebutuhan pasar, maka pemerintah melalui otorita batam mengadakan kerjasama konsesi pengolahan air bersih dengan PT.Adhya Tirta Batam (ATB) untuk mengelola air bersih di Batam selama 25 tahun, mulai tahun 1995 hingga 2020. ATB merupakan perusahaan pengelola air minum swasta pertama di Indonesia (Moreno Ginting, 2015).

Sebagai suatu bentuk perusahaan PT. ATB memiliki visi dan misi sebagaimana organisasi lainnya. PT. ATB memiliki visi untuk menjadi perusahaan air yang terpercaya di Indonesia. Oleh karena itu, agar visi itu tercapai maka diperlukan sistem operasional yang berdedikasi tinggi. Gaya kepemimpinan seorang direktur sangat dibutuhkan dalam mempengaruhi bawahannya, sehingga dapat menciptakan SDM yang berkualitas untuk mengelola suatu perusahaan yang bergerak dibidang pelayanan air bersih di Pulau Batam (ATB, 2016).

Salah satu hal yang menarik untuk dikaji dan dianalisis lebih cermat adalah gaya kepemimpinan direktur operasional PT. Adhya Tirta Batam (ATB) Batam dalam memimpin perusahaan PDAM dan berbagai dinamika dan masalah dalam memimpin perusahaan. Salah satu masalah yang dihadapi adalah tingkat kedisiplinan para pegawai yang masih rendah terutama menyangkut kehadiran. Hal ini terjadi hampir seluruh pegawai terutama pada divisi operasional, hal ini merupakan pekerjaan direktur operasional untuk menyelesaikan kasus atau masalah yang sudah terjadi berlarut-larut sekian lama. Fenomena ini ditambah para pegawai 
yang mengalami penurunan kinerja sehingga pekerjaan diselesaikan tidak tepat waktu, sehinga pekerjaan bertambah di hari berikutnya. Menurut penuturan sebagian pegawai Atb Batam kinerja antara divisi satu dengan yang lain kurang koordinasi, sehingga pekerjaan yang seharusnya selesai tepat waktu menjadi terbengkalai dan hal ini pimpinan direktur tidak mengetahui fenomena yang terjadi diinternal divisi operasional dan menurut laporan tidak ada masalah diinternal divisi dan sesama pegawai di ATB Batam. selain itu kurangnya motivasi dan komunikasi direktur operasional Zulkhairi terhadap pegawai, yang menimbulkan pegawai tidak memahami pemimpinnya. Komunikasi terjalin hanya level manager sehingga untuk manager kebawah terasa jauh hubungan emosionalnya. Hubungan harmonisasi tidak akan terjadi jika pemimpin hanya komunikasi pihak tertentu dan tidak ada sosialisasi ke pegawai yang ada di setiap departemen. Suatu bentuk tugas dari divisi operasional yang ada di ATB meliputi diantaranya :

1. Kualitas air yang diproduksi untuk dikonsumsi oleh pelanggan.

2. Pendistribusikan air yang sudah di produksi kepada pelanggan sehingga air sampai pada sasaran.

3. Pelayanan mengenai kebocoran yang terjadi di masyarakat agar penangganan secara cepat dan tepat.

\section{Permasalahan}

Kualitas kinerja setiap pegawai di masing-masing divisi sangat tergantung pada gaya kepemimpinan dari kepala divisi tersebut. Perbedaan gaya kepemimpinan sering menimbulkan kecemburuan antar divisi. Jumlah pegawai di PT. ATB berjumlah 597 orang, yang terutama didivisi operasional berjumlah 303 orang yaitu meliputi : produksi 110 orang, distribusi 60 orang dan Non Revenue Water (NRW) berjumlah 123 orang. Berikut ini merupakan data dari produksi di setiap WTP untuk di distribusikan ke pelangan yaitu: 
Tabel 1 Data Produksi ATB

\begin{tabular}{cccc} 
No. & WTP & Inst. cap & Treated \\
\hline 1. & Duriangkang & $2200 \mathrm{~m} 3 / \mathrm{s}$ & $2050 \mathrm{~m} 3 / \mathrm{s}$ \\
2. & Nongsa & $60 \mathrm{~m} 3 / \mathrm{s}$ & $36 \mathrm{~m} 3 / \mathrm{s}$ \\
3. & Piayu & $300 \mathrm{~m} 3 / \mathrm{s}$ & $136 \mathrm{~m} 3 / \mathrm{s}$ \\
4. & Ladi & $240 \mathrm{~m} 3 / \mathrm{s}$ & $185 \mathrm{~m} 3 / \mathrm{s}$ \\
5. & Harapan & $60 \mathrm{~m} 3 / \mathrm{s}$ & $36 \mathrm{~m} 3 / \mathrm{s}$ \\
6. & Muka Kuning & $600 \mathrm{~m} 3 / \mathrm{s}$ & $555 \mathrm{~m} 3 / \mathrm{s}$ \\
\hline
\end{tabular}

Sumber: PT. ATB, 2017

Analisis Tabel 1 yang ada diatas terlihat bahwa di masing-masing WTP terlihat target dari produksi belum mencapai harapan yang diinginkan. Namun realisasi air yang diproduksi tidak jauh juga dengan target yang sudah ditentukan dari perusahaan. Dengan hasil produksi yang tidak sesuai dengan target tentunya pelayanan air bersih ke pelangan juga tidak semua akan sampai dengan yang diharapkan pelangan. Apalagi rumah yang letaknya jauh dan letak lokasi yang tinggi tentunya air yang mengalir juga tidak sesuai harapan, ada yang dapat air hanya malam hari dan tidak sedikit juga yang mengalir 24jam secara penuh.

Masalah lain dikarenakan juga bocor yang tidak diketahui sehingga air yang sudah diproduksi tidak mencapai sasaran, sesuai dengan data terakhir tingkat kebocoran sekitar 14,54\% dan jumlah pelangan sesuai data terakhir berkisar 275.646 pelangan diseluruh Kota Batam. Selain itu, berdasarkan observasi yang dilakukan di PT. ATB Pihak top management perusahaan juga terus untuk melakukan inisiatif atau memberikan motivasi kerja kepada pegawai untuk dapat lebih baik lagi dalam bekerja dan adanya kesempatan untuk mengembangkan kemampuan dalam bekerja pada masing-masing divisi yang ada di PT. Adhya Tirta batam (ATB) Kantor Cabang Water Treatment Plant (WTP) Dam Muka Kuning Batam. Oleh karena itu sangat dibutuhkan motivasi yang sangat baik dari level top 
management PT. Adhya Tirta Batam (ATB) untuk dapat mengembangkan kemampuan bekerja para pegawai menjadi semakin baik lagi kedepannya sesuai dengan tujuan perusahaan ataupun memberikan pelatihan-pelatihan khusus sehingga pegawai mempunyai skill atau keahlian khusus sehingga pekerjaan lebih maksimal dan tujuan dari perusahaan PT. Adhya Tirta Batam (ATB) dapat tercapai.

\section{METODOLOGI}

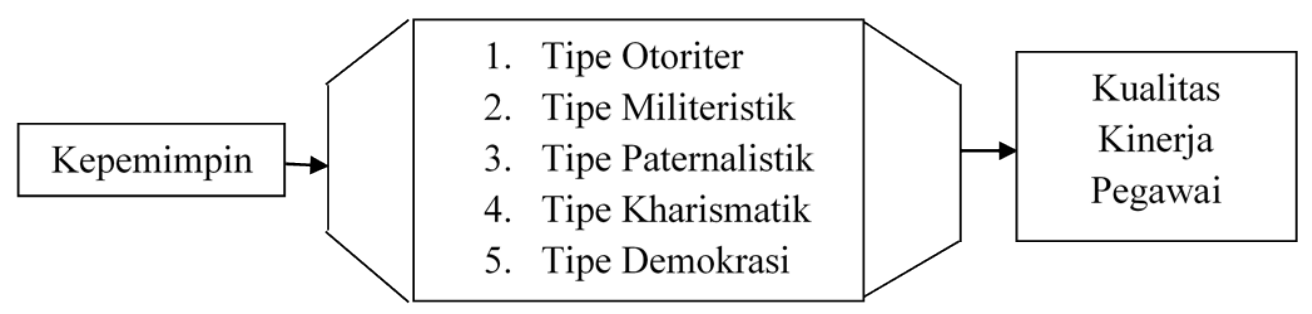

\section{Gambar 1 Kerangka Pemikiran}

Pada penelitian ini peneliti menggunakan metode penelitian kualitatif, metode penelitian kualitatif merupakan metode penelitian yang berlandaskan pada falsafat postpositivisme, digunakan untuk meneliti pada kondisi obyek yang alamiah, dimana peneliti adalah sebagai instrumen kunci, teknik pengumpulan data dilakukan secara triangulasi, analisis data bersifat induktif, dan hasil penelitian kualitatif lebih menekankan makna dari pada generalisasi (Sugiono, 2014). 
Tabel 2

Daftar Sampel Penelitian

\begin{tabular}{ccc}
\hline No & Nama Responden & Jumlah \\
\hline 1. & Manajer Produksi & 1 \\
2. & Manajer Distribusi & 1 \\
3. & Manajer NRW & 1 \\
4. & Supervisor Produksi & 1 \\
5. & Supervisor Distribusi & 1 \\
6. & Supervisor NRW & 1 \\
7. & Foreman Produksi & 1 \\
8. & Foreman Distribusi & 1 \\
9. & Foreman NRW & 1 \\
10. & Teknisi Produksi & 7 \\
11. & Teknisi Distribusi & 7 \\
12. & Teknisi NRW & 7 \\
& & $\mathbf{3 0}$ \\
\hline
\end{tabular}

Sumber: Hasil Pengolahan Data, 2017

\section{PEMBAHASAN}

Pada pembahasan ini, terlebih dahulu ditampilkan Gambar 2 Wilayah Kota Batam, untuk memberikan ilustrasi letak geografis Kota Batam.

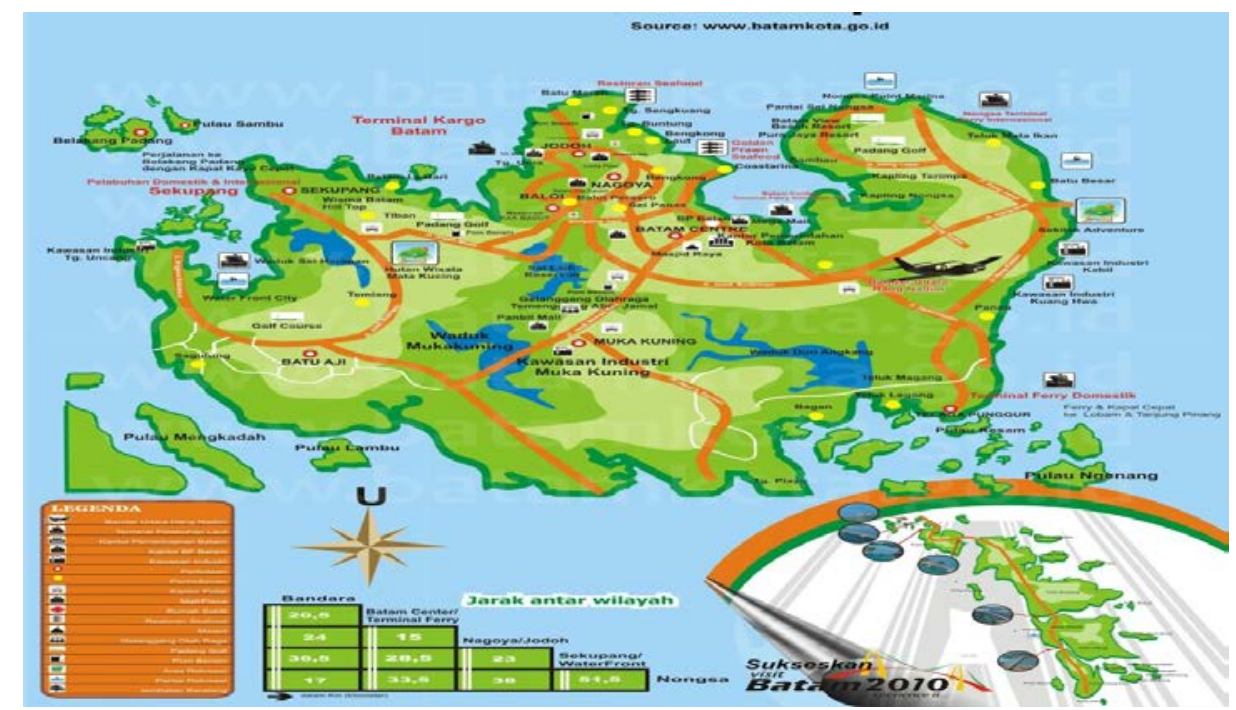

Gambar 2 Wilayah Kota Batam

Sumber: PT. ATB, 2017 


\section{Tipe-tipe Kepemimpinan}

Menurut Kartini Kartono (2016) menjelaskan bahwa tipe kepemimpinan terbagi atas lima tipe yaitu:

\section{Tipe Otoriter}

Seorang pemimpin yang sifatnya otokratis memiliki ciri-ciri dalam kepemimpinannya sebagai berikut:

a) Menganggap organisasi sebagai milik pribadi.

b) Mengindentikan tujuan pribadi dengan tujuan organisasi.

c) Tidak menerima kritik, saran, dan pendapat.

d) Terlalu tergantung kepada kekuasaan formilnya.

e) Dalam tindakan penggerakannya sering mempergunakan pendekatan yang mengandung unsur-unsur pemaksaan dan punitif (bersifat menghukum).

Berdasarkan ciri-ciri di atas dapat di lihat bahwa tipe kepemimpinan otokratis kurang atau bahkan tidak tepat untuk suatu organisasi atau kelompok masyarakat saat ini dimana hakhak asasi manusia menjadi anggota organisasi atau kelompok masyarakat tersebut juga harus dihormati.

\section{Tipe Militeristik}

Seorang pemimpin dengan tipe militeristis tidak berarti selalu seorang pemimpin dari organisasi militer. Seorang pemimpin yang bertipe militeristik adalah seorang pemimpin yang memiliki ciri-ciri dalam kepemimpinannya sebagai berikut:

a) Dalam menggerakan dan mengarahkan bawahannya lebih sering mempergunakan sistem perintah.

b) Dalam menggerakan bawahan senang bergantung pada pangkat dan jabatannya.

c) Menuntut disiplin yang tinggi dan kaku dari bawahan.

d) Sukar menerima kritik dari bawahannya.

Berdasarkan ciri-ciri diatas maka dapat dilihat bahwa seorang pemimpin yang militeristik bukanlah pemimpin yang ideal dalam suatu masyarakat sipil karena akan membungkam aspirasi warga. Sesuai dengan namanya, tipe ini selayaknya diterapkan di kalangan militer yang secara organisatoris memang memiliki struktur yang hierarkis. 


\section{Tipe Paternalistik}

Seorang pemimpin bertipe paternalistis memiliki ciri-ciri dalam kepemimpinannya sebagai berikut:

a) Bersikap terlalu melindungi (Overprotective).

b) Jarang memberikan kesempatan kepada bawahannya untuk menganggap bawahannya sebagai manusia yang tidak dewasa.

c) Jarang memberikan kesempatan kepada bawahannya untuk mengambil inisiatif.

d) Sering bersikap maha tahu.

Tipe kepemimpinan paternalistik berkembang dimasa lalu oleh karena kecenderungan pola hubungan patron-klien dalam masyarakat, dimana pemimpin merupakan figur yang serba hebat dan harus ditiru dan diikuti oleh masyarakat sebagai klien. Tipe ini banyak juga merupakan reproduksi pola hubungan dalam kluarga di masyarakat yang menganut sistem paternalistik dimana peran utama ada pada seorang bapak/suami, dimana istri dan anak-anak harus tunduk pada suami/bapak.

\section{Tipe Kharismatik}

Tipe pemimpin karismatis ini meiliki kekuatan energi, daya tarik, dan perbawa yang luar biasa untuk mempengaruhi orang lain, sehingga ia mempunyai pengikut yang sangat besar jumlahnya dan pengawal-pengawal yang bisas dipercaya. Sampai sekarang pun orang tidak mengetahui benar sebab-sebabnya, mengapa seseorang itu memiliki karisma yang begitu besar. Dia dianggap mempunyai kekuatan ghaib (Supernatural Power) dan kemampuankemampuan yang superhuman, yang diperolehnya sebagai karunia Yang Mahakuasa. Dia banyak memiliki inspirasi, keberanian dan berkeyakinan teguh pada pndirian sendiri. Totalitas kepribadian pemimpin itu memancarkan pengaruh dan daya tarik yang amat besar.

\section{Tipe Demokrasi}

Seorang pemimpin yang demokrasi memiliki ciri-ciri dalam kepemimpinannya sebagai berikut: 
a) Selalu berusaha menyelaraskan kepentingan dan tujuan organisasi dengan kepentingan dan tujuan pribadi dari para bawahannya.

b) Senang menerima saran, pendapat dan bahkan kritik dari bawahannya.

c) Selalu berusaha mengutamakan kerjasama dan kerja tim dalam usaha mencapai tujuan.

d) Dengan ikhlas memberikan kebebasan yang seluas-luasnya kepada bawahannya untuk berbuat kesalahan yang kemudian dibandingkan dan diperbaiki agar bawahannya itu tidak lagi berbuat kesalahan yang sama, tetapi tetap berani untuk berbuat kesalahan yang lain.

\section{Analisis Tipe kepemimpinan Direktur Operasional Terhadap Kualitas Kinerja Pegawai PT. Adhya Tirta Batam (ATB)}

Hasil dari analisis oleh peneliti mengenai tipe Kepemimpinan demokrasi, bahwa kepemimpinan dari direktur operasioanal memiliki karakter pemimpin yang partisipasif dengan selalu memperhatikan kepada bawahannya untuk melakukan inisiatif dan inovatif dalam bekerja demi kemajuan perusahaan. Pejabat dibawah direktur operasioanl juga diberikan kebebasan untuk menyampaikan saran, pendapat ataupun kritik yang tujuannya bersama-sama untuk kemajuan agar lebih baik lagi. Kepemimpinan seperti ini sangat pantas untuk diterapkan diperusahaan, dimana pemimpin secara bebas memberikan wewenang dan tugas kepada bawahannya sesuai dengan jabatan tetentu di perusahaan. Kepemimpinan direktur juga sangat bagus dengan berusaha mengutamakan kerjasama dan kerja tim dalam setiap pekerjaan ataupun projek dari perusahaan. Hal ini tentunya membawa pengaruh yang sangat positif untuk pegawai dalam bekerja. Bahwa pendapat dari beberapa pegawai juga sama dengan pendapat yang diungkapkan oleh peneliti sehingga direktur sangat cocok dengan tipe kepemimpinan demokrasi yang digunakan diperusahaan PT. Adhya Tirta Batam (ATB).

Perusahaan sangat cocok dengan tipe ini sehingga kemajuan perusahaan memperoleh lebih maksimal sesuai dengan tujuan, visi dan misi dari perusahaan PT. Adhya Tirta Batam (ATB). Dari tipe kepemimpinan yang digunakan oleh direktur tidak terlepas dari kepribadian dari direktur operasional ATB, yang lebih mempunyai sifat ramah dan juga responsif terhadap permasalahan yang sedang dihadapi oleh perusahaan yang dipimpinnya. Zulkhairi selaku direktur operasional PT. Adhya Tirta Batam (ATB) memiliki latar belakang yang kuat 
dibidang operasional dan pengembangan bisnis dalam sektor utilitas. Sejak bergabung dengan sembcorp grup ditahun 1998, beliau sudah menangani berbagai bidang teknis dan komersial di sembcrop dibidang energi dan air pada hub petrokimia singapura di pulau jurong. Beliau juga bekerja di departemen pengembangan bisnis sembcorp dan merupakan bagian dari tim yang bertanggung jawab untuk mengevaluasi dan mengamankan proyek-proyek baru dibidang energi, air dan limbah. Selain itu Zulkhairi pasuni juga berperan memberikan dukungan teknis dan dan operasional untuk energi dan aset air di ASEAN. Beliau yang memegang gelar Master of Engineering dari ESSIE Paris di Prancis. Beliau selain sebagai direktur di ATB, beliau sebagai pemimpin yang luar biasa terlihat juga sangat berperan aktif dalam pengelolaan energi, air dan limbah yang ada di Asean.

Tipe kepemimpinan dapat diartikan sebagai bentuk atau pola atau jenis kepemimpinan, yang didalamnya diimplementasikan satu atau lebih perilaku atau gaya kepemimpinan sebagai pendukungnya. Sedangkan gaya kepemimpinan diartikan sebagai perilaku atau cara yang dipilih dan dipergunakan pemimpin dalam mempengaruhi pikiran, perasaan, sikap dan perilaku para anggota organisasi atau bawahannya.

Aspek sumber daya manusia memegang peranan penting dan paling dominan dalam sebuah organisasi. Manajemen seumber daya manusia merupakan bagian yang tidak terpisahkan dari manajemen pada umumnya, yakni merupakan kunci utama dalam pencapaian tujuan organisasi. Faktor-faktor yang mempengaruhi kinerja pegawai antara lain kepemimpinan, lingkungan kerja, kepuasan kerja, dan lain-lain. Berdasarkan hasil penelitian diperoleh bahwa tipe kepemimpinan berpengaruh positif dan signifikan terhadap kinerja pegawai. Kepemimpinan merupakan faktor penting dalam memberikan pengarahan kepada pegawai apalagi pada saat sekarang ini dimana semua serba terbuka, maka kepemimpinan yang dibutuhkan adalah kepemimpinan yang bisa memberdayakan pegawai.

Berdasarkan hasil pengamatan yang dilakukan dilapangan tipe kepemimpinan yang dominan diterapkan adalah tipe kepemimpinan demokrasi, tetapi dalam hal tertentu direktur lebih menerapkan tipe kepemimpinan yang militeristik dalam menyangkut penegakkan kedisiplinan bagi pegawai dalam lingkungan organisasi PT. Adhya Tirta Batam untuk memaksakan pelayanan yang prima kepada masyarakat. Gaya kepemimpinan banyak 
mempengaruhi keberhasilan seorang pemimpin dalam mempengaruhi bawahannya. Salah satunya gaya kepemimpinan demokratis yang merupakan perilaku yang digunakan oleh seorang pada saat orang tersebut mencoba mempengaruhi perilaku orang lain.

Hal ini ditinjau dari indikator tipe kepemimpinan demokratis yang diterapkan oleh direktur operasional PT. Adhya Tirta Batam. Dalam membuat suatu keputusan secara Bersama, perilaku pemimpin yang senantiasa sebelum menetapkan hasil terlebih dahulu merundingkan kepada para bawahannya melalui musyawarah ataupun diskusi. Dalam hal menghargai potensi setiap bawahannya, tercermin pada saat pimpinan menghargai para bawahannya yang memiliki potensi dan prestasi yang sangat baik. Mendengar kritik, saran dan pendapat bawahan terlihat bahwa pemimpin pada divisi operasional PT. Adhya Tirta Batam bersifat terbuka terhadap bawahan dalam menyampaikan saran dan pendapat dari para pegawai yang menyangkut masalah organisasi, hal ini biasa dilakukan saat rapat dalam membahas pekerjaan. Melakukan kerjasama dengan bawahan disetiap pekerjaan, terlihat pada perilaku pemimpin yang selalu mengontrol dan membimbing para bawahannya dalam melakukan aktivitas pekerjaan.

Kepemimpinan direktur operasional dengan menerapkan tipe kepemimpinan demokrasi sangat berpengaruh terhadap pegawai di setiap departemen untuk meningkatkan kinerja para pegawai. Hasil dari wawancara beberapa pegawai dari setiap departemen hipotesis yang diterima pengaruh anrtara direktur operasional dengan pegawai masih berpengaruh rendah, hal ini terlihat kurangnya pemimpin turun langsung dalam melihat pekerjaannya secara langsung yang dilakukan oleh para bawahannya dilapangan. Semua tugas dan tanggung jawab pekerjaan yang diberikan, pemimpin memberikan kepercayaan penuh terhadap hasil akhir dari pekerjaan yang telah dilakukan oleh bawahannya.

Para pegawai juga melakukan kerjasama dengan rekan sekerjanya, atasan serta instansi lain dengan menyelesaikan suatu pekerjaan tertentu, selain itu juga para bawahan mampu menerima pendapat dan dari orang lain, serta bersedia menerima keputusan yang diambil secara sah yang telah menjadi keputusan Bersama. Pemimpin mampu bertindak secara tegas dan tidak memihak ataupun sepihak dengan memberikan teladan yang baik, kemampuan menggerakkan tim kerja untuk mencapai kinerja yang tinggi, mampu menggugah semangat 
dan menggerakkan bawahannya dalam melaksanakan tugas dan tanggung jawab serta mampu mengambil keputusan dengan cepat dan tepat.

\section{KESIMPULAN DAN SARAN}

\section{Kesimpulan}

Berdasarkan uraian pada hasil pembahasan diatas, peneliti menyimpulkan hasil penelitian bahwa dari hasil wawancara dengan beberapa informan dapat disimpulkan bahwa Direktur Operasional dalam memimpin memiliki tipe kepemimpinan demokrasi dimana pegawai sangat berperan penting dalam kemajuan perusahaan. Seorang pemimpin memberikan kepercayaan dalam tugas dan wewenangnya didalam organisasi dan juga pengambilan keputusan didalam pekerjaan yang diberikan oleh perusahaan.Pegawai diberikan kebebasan untuk berinisiatif dan berinovasi terhadap perusahaan. Pemimpin juga diberikan kesempatan untuk memberikan masukan, saran, pendapat dan kritik kepada pemimpin jika keputusan yang diambil pemimpin itu kurang tepat untuk perusahaan tetapi tetap pengambilan keputusan oleh direktur operasional. Pemimpin juga menyelaraskan kepentingan organisasi dan kepentingan antara pegawainya. Selain daripada itu pemimpin selalu berusaha untuk mengutamakan kerjasama dan kerja tim dalam mencapai tujuan perusahaan, hal ini sangat berpengaruh yang signifikan untuk kemajuan dan kenyaman kerjaan pegawai.

\section{Saran}

Dari hasil penelitian yang dilakukan, saran yang dapat diberikan kepada Direktur Operasional lebih meningkatkan keakraban kepada seluruh pegawai, sehingga pegawai lebih mengenal kepribadian pemimpin, dengan melalui pertemuan disetiap departemen yang dipimpinnya atau setiap ada acara yang dibuat oleh setiap departemen yang ada diperusahaan. Hal lain adalah agar Direktur Operasional lebih sering meninjau langsung pekerjaan bawahannya, sehingga bawahannya merasa lebih diperhatikan dan juga lebih dekat pegawai dengan pemimpinnya, sehingga terjalin komunikasi yang baik bukan di level manager tetapi semua level yang ada dibawah direktur. 


\section{REFERENSI}

Arifin, Syamsul, 2012. Leadership. Jakarta: Penerbit Mitra Wacana.

B. Mathew dan Michael Huberman.1992.Analisis Data Kualitatif, Jakarta: UIP.

Bintoro dan Daryanto, 2017. Manajemen Penilaian : Kinerja pegawai. Penerbit Gava Media : Yogyakarta.

Cummings dan Schwab, 1973. Performance In Organizations: Determinants and Appraisal. Glenview, Illinois: Scott, Foresman and company.

Fahmi, Irham, 2013. Manajemen Kepememimpinan.Bandung : Penerbit Alfabeta.

Gaspersz, Vincent. 2002. Manajemen Kualitas dalam Industri Jasa. Jakarta: PT. Gramedia Pustaka Utama.

Hamidi. 2004. Metode Penelitian Kualitatif, Aplikasi Praktis Pembuatan Proposal dan Laporan Penelitian, Malang: UMM Press.

Handoko, T. Hani. 2007. Manejemen Personalia. Jogyakarta: BPFE-UGM.

Hao, Laoshi,2013,skripsi, Pelaksanaan Reformasi Birokrasi DalamMeningkatkan Kualitas Kerja Pegawai Di Kantor Pertanahan Kota Banjar, hal 3, ,http;//www.academia.edu/7734065/BAB 1 SKRIPSI 82.

Kartini, Kartono, 2016. Pemimpin dan Kepemimpinan. PT. Raja grafindo Persada : Jakarta.

Kartini Kartono, 2014. Pemimpin dan Kepemimpinan. CV rajawali : Jakarta.

Kartini Kartono, 1998. Pemimpin dan Kepemimpinan. Jakarta : CV rajawali.

Katzenbach, Jon R.2006. Real Change Leader. Jakarta : Professional Books.

Lexy JMaleong,MetodePenelitian Kualitatif, Bandung: Remaja Rosdakarya, 2000.

Luthans, Fred. 2006. Perilaku Organisasi : Yogyakarta : Andi.

Mangkunegara. 2009. Manajemen Sumber Daya Manusia. PT. Remaja Rosda karya : Bandung.

Mardalis. 1999.Metode Penelitian Suatu Pendekatan Proposal, Jakarta : BumiAksara. Marwansyah.2012.manajemen sumber daya manusia. Bandung: CV Alfabeta. Mifta Thoha. 2003. Kepemimpinan Dalam Manajeme. Jakarta: Rajawali Pers. Moh. Panbudu Tika H.2005. Metode Penelitian Geografi. Jakarta : Bumi Aksara. Moekijat, 2002. Tata Laksana, Manajemen Perkantoran: Mandar Maju. Bandung 
Moreno Ginting, Enriqo, 2015. ATB Untuk Batam. Batam : PT. Adhya Tirta Batam.

Satori Djama’an dan Komariah Aan. 2007. Metodologi Penelitian Kualitatif, Bandung: Alfabeta. Cet, 7.

Siagian, Sondang P. 2006. Manajemen Sumber Daya Manusia. Jakarta: Penerbit Bumi Aksara. Sugiyono, Metode Penelitian Kuantitatif Kualitatif dan R\&D, Bandung: Alfabeta, 2009, Cet. Ke 8.

Sugiyono.2012. Memahami Penelitian Kualitatif. Bandung : AL FABETA.

Sugiyono.2013.Metode Penelitian Kuantitatif, Kualitatif, dan $R$ \& D, Bandung: ALFABETA. Sugiono. 2014. Metode Penelitian Kuantitatif, Kualitatif, Dan R\&D : CV Alfabeta. Bandung. Suharsimi Arikunto.2010. Prosedur Penelitian Suatu PendekatanPraktik. Jakarta.PT. RINEKA CIPTA.

Verill M. Law \& W. David Kelton,1991.Simulation Modeling \& Analysis, second edition: McGraw-Hill. 